\title{
1. ISLAS ORCADAS RISE AND METEOR RISE: THE TECTONIC AND DEPOSITIONAL HISTORY OF TWO ASEISMIC PLATEAUS FROM SITES 702, 703, AND 7041
}

\author{
Carol A. Raymond, ${ }^{2}$ John L. LaBrecque ${ }^{2}$ and Yngve Kristoffersen ${ }^{3}$
}

\begin{abstract}
Data from recent geophysical surveys of the conjugate Islas Orcadas and Meteor rises in the South Atlantic are discussed in relation to results of ODP Leg 114 drilling of these features. We examine morphology and the nature of basement on the two rises and correlate seismic horizons with the drilled stratigraphy to establish a depositional history for each rise. Basement on Islas Orcadas Rise is generally smoother than on Meteor Rise, and there is evidence for a younger phase of volcanism on Meteor Rise. Meteor Rise has experienced a more dynamic depositional history, whereas flat-lying sediments on Islas Orcadas Rise are disrupted by Neogene faulting. Paleodepth estimates indicate that significant topography existed during the Paleocene-early Eocene, that the plateau portions of the rises formed below sea level, and that only the seamounts on the Meteor Rise appear to have formed on-ridge. We speculate that the rises formed in the Late Cretaceous-early Tertiary, and that a second phase of volcanism occurred on the Meteor Rise, contemporaneous with the initiation of seafloor spreading that separated the rises at $59 \mathrm{Ma}$.
\end{abstract}

\section{INTRODUCTION}

The Islas Orcadas and Meteor rises in the South Atlantic (Figs. 1 and 2) are conjugate aseismic ridges that were first recognized and described by LaBrecque and Hayes (1979). These features are thought to have formed during the Late Cretaceous-early Paleocene at the site of rifting of old (20 m.y.) oceanic lithosphere. The rift zone formed when the spreading center just south of the Falkland-Agulhas Fracture Zone jumped $825 \mathrm{~km}$ west (du Plessis, 1977; Barker, 1979; LaBrecque and Hayes, 1979). These conjugate rises are thought to have formed as a single structure, which subsequently broke and drifted apart at approximately Chron C25 (59 Ma; Kent and Gradstein, 1986). The site survey cruises for Ocean Drilling Program (ODP) Leg 114 included a Polar Duke (0186) survey of the Islas Orcadas Rise in the southwestern South Atlantic and a survey of the Meteor Rise in the southeastern South Atlantic (Indo-Atlantic) by Robert $D$. Conrad (2710). The tectonic objectives of Leg 114 were to test the age and evolution of these anomalous morphotectonic features and their conjugate origin. An ancillary objective was to evaluate the influence of these rises on paleocirculation in the Southern Oceans. Here we present a synthesis of the data from the site surveys and discuss the tectonic and depositional history and paleodepth of the Meteor and Islas Orcadas rises as well as possible models for their origin.

\section{MORPHOLOGY}

A generalized bathymetric map of the southern South Atlantic is presented in Figure 1, showing the Meteor and Islas Orcadas rises in their present configuration. The younger seafloor between the rises was created at the South Atlantic spreading center and displays no anomalous attributes, implying that the conditions that were responsible for the creation of the aseismic plateaus had dissipated. Maps presented in

\footnotetext{
${ }^{1}$ Ciesielski, P. F., Kristoffersen, Y., et al., 1991. Proc. ODP, Sci. Results, 114: College Station, TX (Ocean Drilling Program).

2 Lamont-Doherty Geological Observatory of Columbia University, Palisades, NY 10964

${ }^{3}$ Seismological Observatory, University of Bergen, Allegaten 41, N-5014 Bergen, Norway.
}

Figures $2 \mathrm{~A}$ and $2 \mathrm{~B}$ show the detailed bathymetry of the two rises with adjacent magnetic anomalies.

\section{Meteor Rise}

The Meteor Rise is a pear-shaped plateau, approximately $300 \mathrm{~km}$ long with a maximum cross-strike width of $150 \mathrm{~km}$, situated in the southeastern South Atlantic (Fig. 2A). It separates Late Cretaceous crust of the western flank of the extinct Agulhas Basin spreading center (older than C34N) from late Paleocene crust of the eastern flank of the active South Atlantic spreading center (C25). The $330^{\circ}$ strike of Meteor Rise conforms to the direction of early Tertiary magnetic anomaly isochrons in the South Atlantic. The Meteor Rise does not extend northward to meet the Agulhas Fracture Zone, as is the case with the Islas Orcadas Rise (Fig. 2B). However, at the intersection of the Meteor Rise trend with the Agulhas Fracture Zone there is a large guyot, which may be genetically related to the formation of Meteor Rise. South of Meteor Rise are numerous seamounts, generally along a northeast-southwest trend. Although some of these seamounts may have formed contemporaneously with the Meteor Rise, others are certainly younger (as they are built upon younger crust).

Meteor Rise has a plateau morphology; the plateau is approximately $1.5 \mathrm{~km}$ shallower than the adjacent ocean basins. At the eastern edge of the plateau a group of seamounts rises more than $1 \mathrm{~km}$ from the surface of the plateau. In this high-relief seamount province, the bathymetric scarp down into the Agulhas Basin has over $3 \mathrm{~km}$ of vertical relief. Atop the southern Meteor Rise, adjacent to the seamounts, lies a $\sim 100 \times 50 \mathrm{~km}$ sedimentary basin, with up to 1.4-s two-way traveltime (twt) of sediment fill. Magnetic anomalies over the Meteor Rise, shown in Figure 3, exhibit a positive correlation with bathymetry over the plateau. East of the plateau, an inverse correlation of magnetic anomaly to bathymetry is observed, implying a reversed magnetization for the seamount province.

\section{Islas Orcadas Rise}

The Islas Orcadas Rise is, in general, deeper than the Meteor Rise and exhibits less overall relief (Fig. 2B). The Islas Orcadas Rise has a ridge morphology, $\sim 500 \mathrm{~km}$ long, with a 


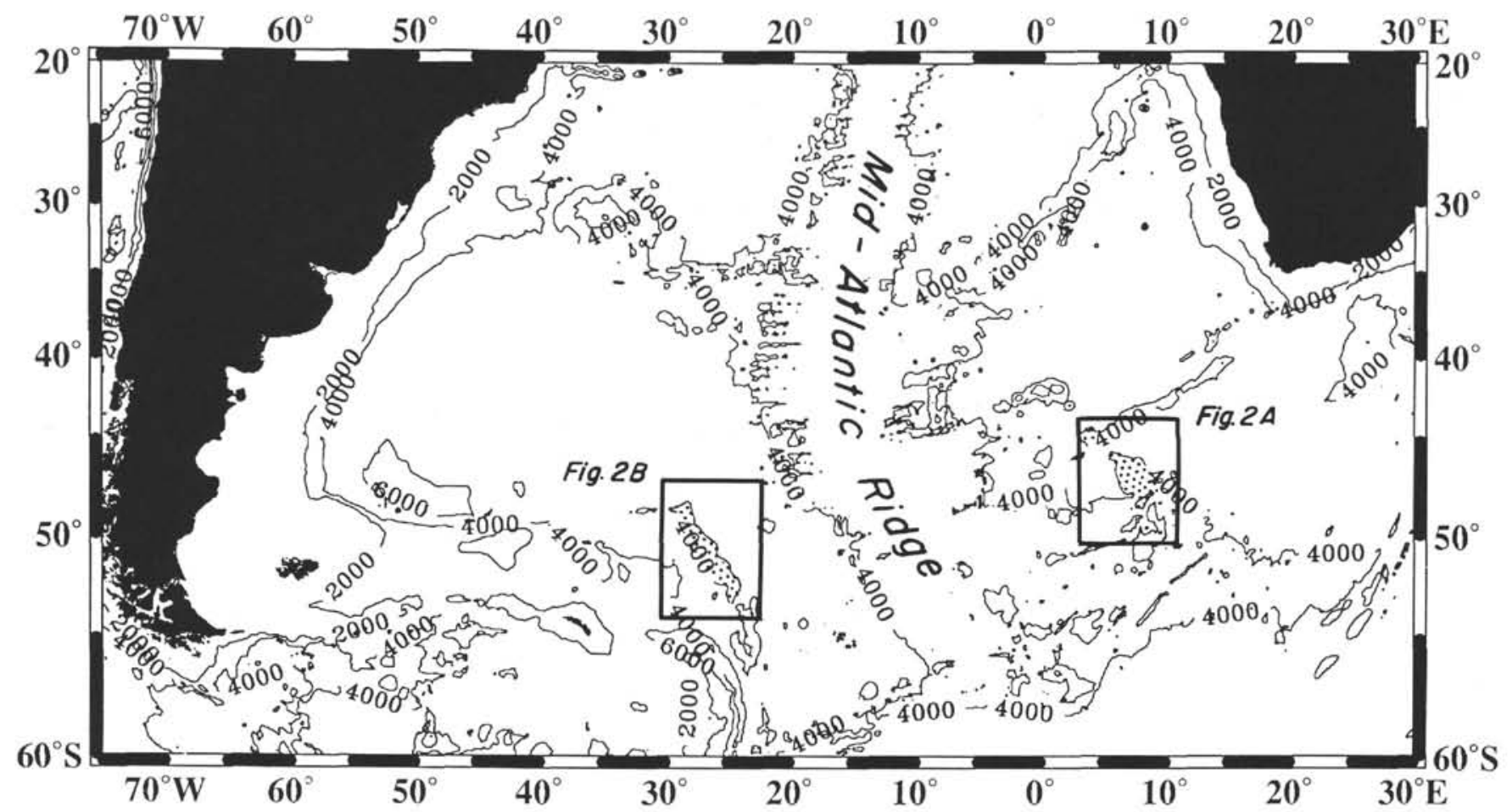

Figure 1. Generalized bathymetric map of the southern South Atlantic. Contour interval is $2000 \mathrm{~m}$. Boxes denote areas of detailed maps presented in Figure 2. Approximations of the Meteor and Islas Orcadas rises are stippled.

cross-strike width of $\sim 150 \mathrm{~km}$ in the south and $70 \mathrm{~km}$ in the north where it joins the Falkland Fracture Zone. The central part of the rise forms a $120 \times 120 \mathrm{~km}$ relatively level plateau (Fig. 2B). The northern limit of the Islas Orcadas Rise is the Falkland Fracture Zone, which exhibits a ridge morphology west of the Islas Orcadas Rise, analogous to the conjugate Agulhas Fracture Zone east of its intersection with the Meteor Rise. The Early Cretaceous Northeast Georgia Rise (Kristoffersen and LaBrecque, this volume) lies just west of the Islas Orcadas Rise on middle Cretaceous crust of the Georgia Basin (see fig. 1 of Brenner and LaBrecque, 1988). The Islas Orcadas Rise, like the Meteor Rise, also conforms to the strike of the early Tertiary magnetic anomalies of the South Atlantic.

The bulk of Islas Orcadas Rise (central plateau) is elevated little more than $1 \mathrm{~km}$ above the adjacent oceanic crust, except for the southern end of the Islas Orcadas Rise, where a prominent group of seamounts striking north-northeast has peaks between 2250 and $1750 \mathrm{~m}$ depth. Deep grabens with the same azimuth separate a ridge of similar trend through the southern end of Islas Orcadas Rise and cut through the northern end of Islas Orcadas Rise, marking the point where its width decreases markedly. No significant magnetic anomaly amplitudes are associated with major changes in basement relief.

In contrast to the Meteor Rise, sediment accumulations on the Islas Orcadas Rise are controlled by a system of horsts and grabens that strike approximately north-south on the central plateau.

\section{NATURE OF THE BASEMENT}

Single-channel seismic data from the Meteor Rise and Islas Orcadas Rise were studied to determine characteristics of the oceanic basement of the rises. Locations of key seismic profiles discussed in the text are indicated on Figures $4 \mathrm{~A}$ and 7.

\section{Meteor Rise}

On the Meteor Rise, the basement topography is generally rugged. Volcanic peaks are ubiquitous, particularly on the northern and southeastern parts of the rise. Toward the center of the rise, a sedimentary layer drapes the irregular topography. Maps of sediment thickness and detailed bathymetry for the southern Meteor Rise are presented in Figures $4 \mathrm{~A}$ and $4 \mathrm{~B}$, respectively. Single-channel seismic data through this area and accompanying line drawings are shown in Figures 5 and 6.

As can be seen from examining Figures 4, 5, and 6, basement of the southern Meteor Rise is characterized by an elliptical depression, with its major axis oriented nearly northsouth, bounded to the west by a basement ridge and to the east by a seamount province. Portions of the west-facing slope of the western basement ridge are very steep; at the western edge the Meteor Rise is dissected by numerous high-angle faults. It is difficult to ascertain whether the faults are normal or reverse. Seamounts and guyots in the east range in depth from 1750 to $1100 \mathrm{~m}$. Basement appears to be faulted from the seamounts down into the basin on two profiles (M-2 and M-5). Some peaks appear to be sediment-free, whereas others are covered by attenuated layers and thicker accumulations are found in the lee of the large seamounts. Within the basement depression, the thickness of basement overburden reaches 1.4-s twt (Figs. 4 and 5).

A distinct and uneven reflection event (hereafter called reflector $\mathrm{Z}$ ) appears about $250 \mathrm{~ms}$ above the interpreted basement reflection in the eastern part of the elliptical basin and merges eastward with the base of the seamount province (Figs. 4-6). Its abrupt westward termination, roughness, and geometry (as an apron surrounding the lower flank of a seamount province) strongly suggest an association with lava flows. Drilling at Site 703 , located in the seamount 


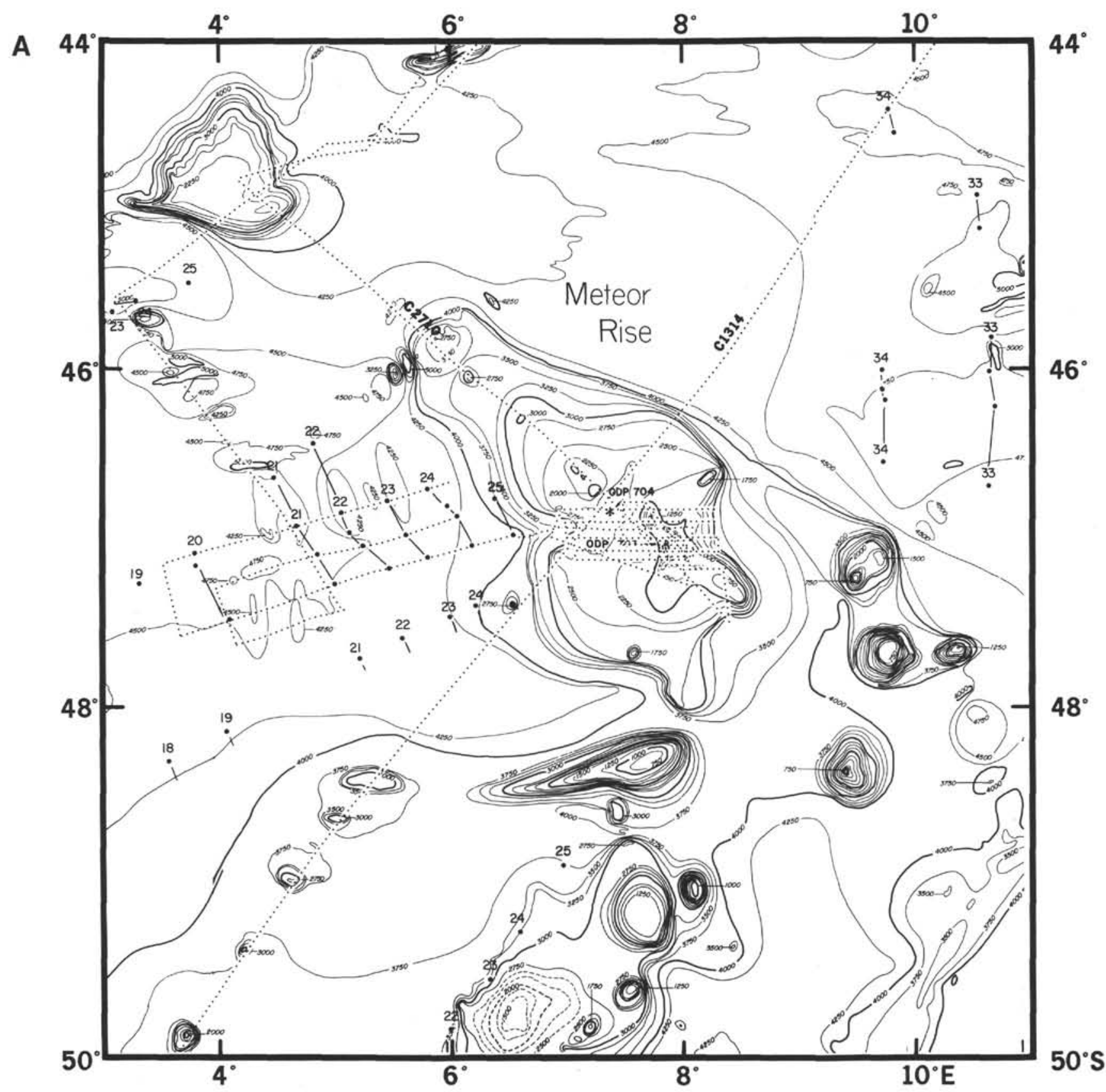

Figure 2. Bathymetric maps of (A) Meteor Rise (from Raymond and LaBrecque, 1988) and (B) Islas Orcadas Rise (from Brenner and LaBrecque, 1988). Contour interval is $250 \mathrm{~m}$. Magnetic anomaly identifications are shown as dots with annotated numbers. The dots are connected by solid lines where lineation direction can be inferred. ODP Leg 114 sites are indicated by asterisks. Dotted lines indicate tracks with single-channel seismic data that were analyzed in this study.

province, recovered highly altered porphyritic basalt, which has been interpreted as basement. The basalt samples range chemically from fairly mafic alkali basalts to evolved hawaiites, trachytes, and quartz-bearing trachytes (M. Perfit, pers. comm., 1989). The oldest sediments above the basalt are early middle Eocene $(\sim 50 \mathrm{Ma})$. Although the available seismic data do not allow a direct tie between basement at this site and the interpreted volcanic layer extending into the basin, we tentatively infer a common volcanic origin for the seamounts and reflector $\mathrm{Z}$. The implications of reflector $\mathrm{Z}$ are discussed later.

\section{Islas Orcadas Rise}

Basement on the Islas Orcadas Rise is considerably smoother than on the Meteor Rise. Islas Orcadas Rise trends $330^{\circ}$, but has at least two oblique $\left(\mathrm{N} 15^{\circ} \mathrm{E}\right)$ basement ridges and depressions superimposed, as is evident in the map of sediment thickness for the central plateau (Fig. 7) and in the seismic data shown in Figure 8A. Basement was not reached at Site 702 , but a basaltic substratum is inferred from the pore-water chemistry (Ciesielski, Kristoffersen, et al., 1988). The band of seismic-reflection events $120 \mathrm{~ms}$ below the 
B



Figure 2 (continued), 


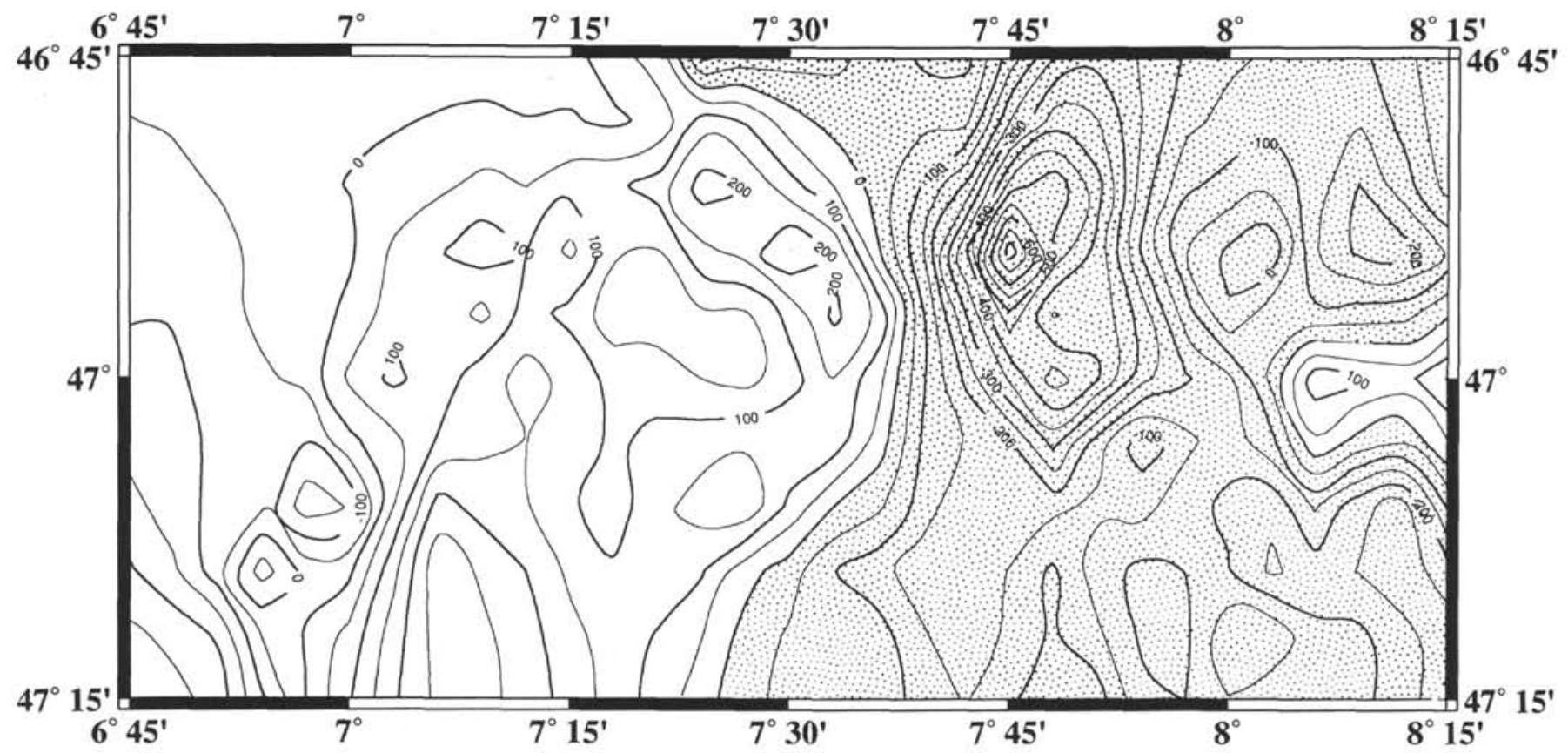

Figure 3. Contoured magnetic anomaly map of the southern Meteor Rise. Contour interval is 50 nanoteslas. Negative anomalies, indicated by the stippled pattern, occur over the seamount province and extend into the basin; the gradient appears to be approximately parallel to the western limit of reflector $\mathrm{Z}$.

bottom of Hole 702B is tentatively interpreted as acoustic basement (Figs. 8A and $8 \mathrm{~B}$ ). The multicycle signature observed at Site 702 is similar to the seismic signature of basement at Site 698 (Northeast Georgia Rise), where drilling recovered basalt with intercalated sediments. This suggests that the upper part of basement on the central plateau of Islas Orcadas Rise may have a similar composition.

The ridge of seamounts bordering the central plateau to the southeast extends more than $1 \mathrm{~km}$ above the plateau level (Fig. 2B). Line IO-4 across this ridge (Fig. 8A) shows evidence of northwest-directed compression, suggesting that a large part of the elevation difference may be controlled by uplift following construction of the seamounts.

\section{AGE OF THE RISES}

New age information has been obtained from drilling on the rises. The age of the Islas Orcadas Rise has been constrained to be older than $62 \mathrm{Ma}$, based on the age of the oldest sediments recovered at Site 702. However, reworked Late Cretaceous microfossils were recovered in the Eocene section, suggesting that the rise may be Late Cretaceous in age. These Late Cretaceous fossils comprise a few calcareous foraminifers and shallow-water organisms such as bivalves, stout echinoid spines and plaques, and heavily ornamented ostracodes (Shipboard Scientific Party, 1988a). There is always the chance that reworked fossils are exotic; therefore, their occurrence cannot be cited as evidence that the Islas Orcadas Rise is Late Cretaceous in age. Basement was obtained at Site 703 in the seamounts at the eastern edge of Meteor Rise. The age of the sediments above the basement is early middle Eocene ( $\sim 50 \mathrm{Ma})$.

In order to reconcile the disparity in ages for the two rises, it is sufficient to assume that both Meteor Rise and Islas Orcadas Rise are older than $62 \mathrm{Ma}$. In that case, a hiatus exists above basement at Site 703, which is reasonable because the present elevation of this site indicates that it formed above sea level, where erosion would have been dominant. The Late Cretaceous fossil age for the Islas Orcadas Rise implies a 20-m.y. hiatus in sedimentation during the Late Cretaceous, Paleocene, and early Eocene at Site 703, if the ages of the rises are coeval. Alternatively, we can assume that the age of basement need not be the same for Sites 702 and 703 . We explore the possibility that the basement on the rises is in fact Late Cretaceous in age and that the basement at Site 703 was emplaced during a later phase of volcanism, contemporaneous with the rifting of the rises and initiation of seafloor spreading at the new spreading center at C25 $(\sim 59 \mathrm{Ma})$.

\section{IMPLICATIONS OF REFLECTOR Z}

The existence of a distinct reflection event within the sedimentary fill at the eastern edge of the basin can be interpreted several ways. We have interpreted the reflector to be a volcanic layer based on its abrupt westward termination, roughness, and geometry as an apron surrounding the seamounts. Reflector $\mathrm{Z}$ may be contemporaneous with the rest of the basement on the Meteor Rise, indicating that the 250-msthick sediment layer was deposited very rapidly on the basement of the plateau prior to the emplacement of reflector $\mathrm{Z}$. This assumption is reasonable given that the rise was close to sea level and large volumes of ash would have been produced by the nearby seamounts. If the time interval between formation of the Meteor Rise basement and reflector $\mathrm{Z}$ is short (several million years), then sedimentation rates must have been $100 \mathrm{~m} / \mathrm{m}$.y. to explain the $250 \mathrm{~ms}$ of sediments between the basement and reflector $\mathrm{Z}$. An alternative hypothesis is that reflector $\mathrm{Z}$ represents a younger phase of volcanism distinct from the formation of the plateau. Based on the expected hiatus at Site 703 , if we assume an age of $\sim 60 \mathrm{Ma}$ for reflector $\mathrm{Z}$, we can estimate the age of the pre-existing basement below the sedimentary basin by extrapolating downward from reflector $\mathrm{Z}$ to the basal reflector, using an average sedimentation rate obtained from Hole $704 \mathrm{~B}(20 \mathrm{~m} / \mathrm{m} . \mathrm{y}$.) and an average seismic velocity of $2 \mathrm{~km} / \mathrm{s}$ in the section. This simple calculation yields a Late Cretaceous age $(\sim 72 \mathrm{Ma})$ for the basement of the Meteor Rise, in accordance with the recovered Late Cretaceous reworked microfossils on the Islas Orcadas Rise. 


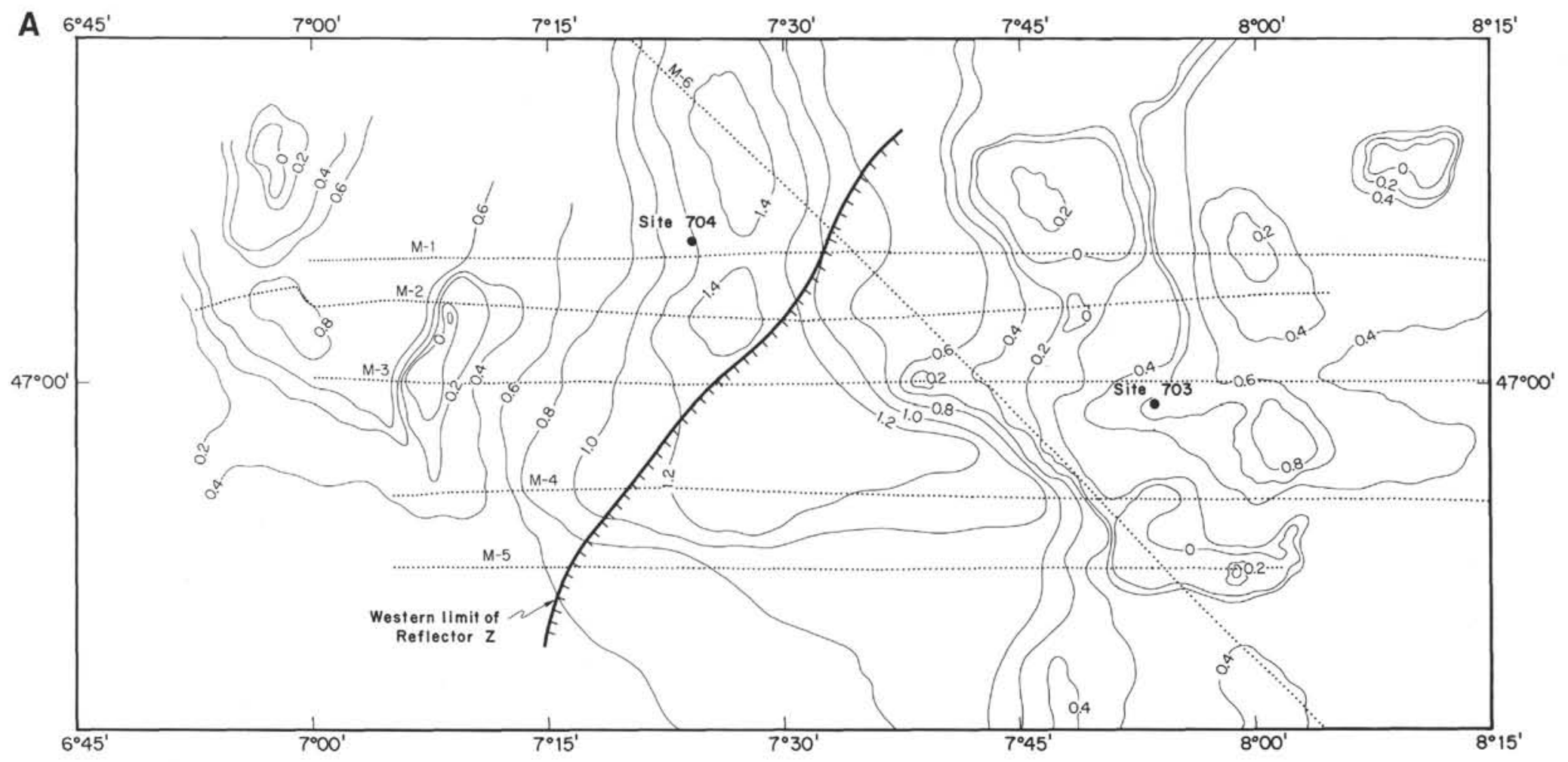




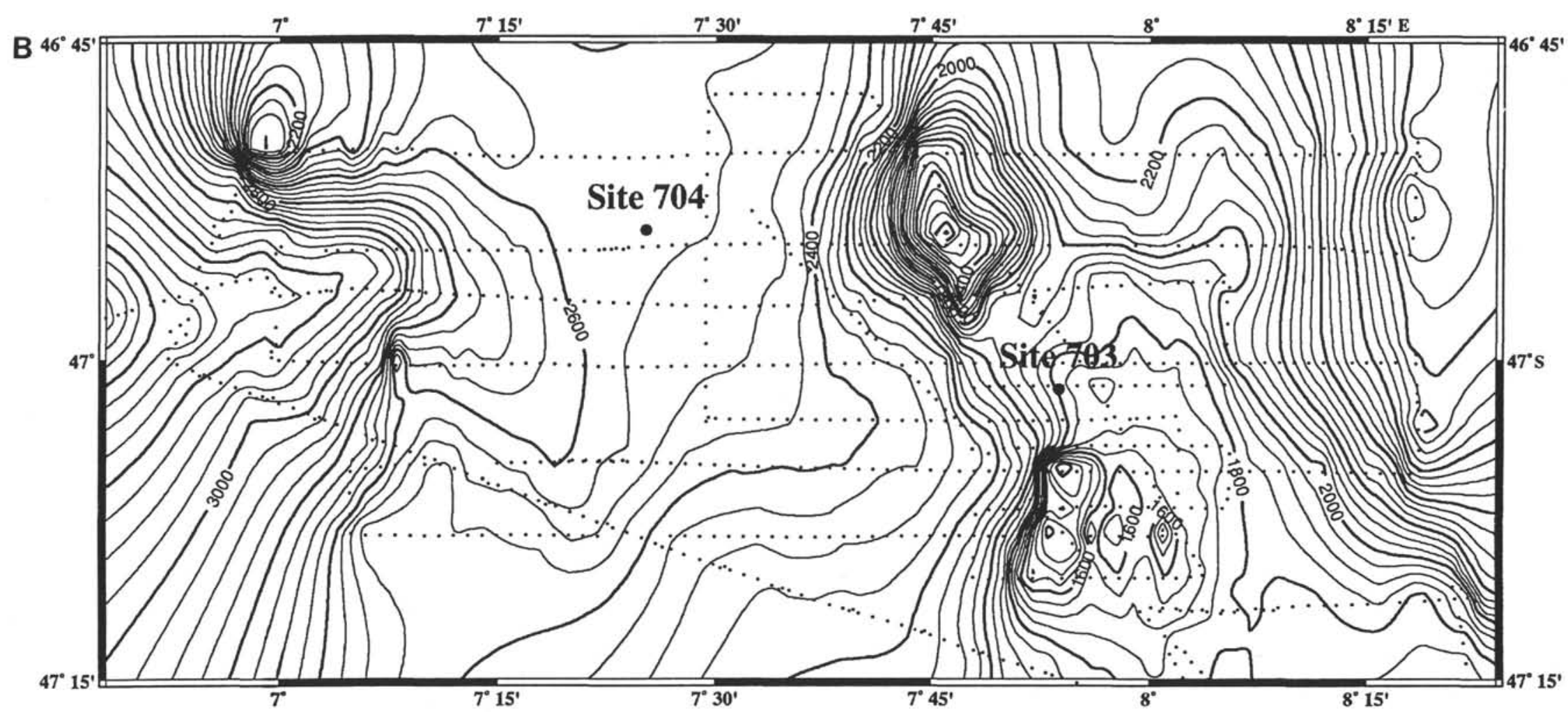

Figure 4. A. Sediment thickness (s twt) map for the southern Meteor Rise. Contour interval is $200 \mathrm{~ms}$, which is approximately $220 \mathrm{~m}$. Several volcanic peaks crop out in the seamount province in the east and along the western basement ridge. Thick sediments $(1.5 \mathrm{~km})$ lie in the axis of the basin, which strikes nearly north-south. Seismic profiles illustrated in Figure 5A are shown as dotted lines with labels. These lines and the tracks shown in Figure 4B were used to construct the map. The ticked line indicates the westernmost extent of reflector Z, which merges with the seamounts in the east (see text for discussion). B. Detailed bathymetric map of the southern Meteor Rise, contoured at $50 \mathrm{~m}$, from gridded SeaBeam data obtained by Conrad 2710. Data control is shown by dots, and ODP sites are marked and labeled. The rough topography at the eastern edge of the Meteor Rise drops off sharply into the smooth, sediment-filled basin. 


\section{A}
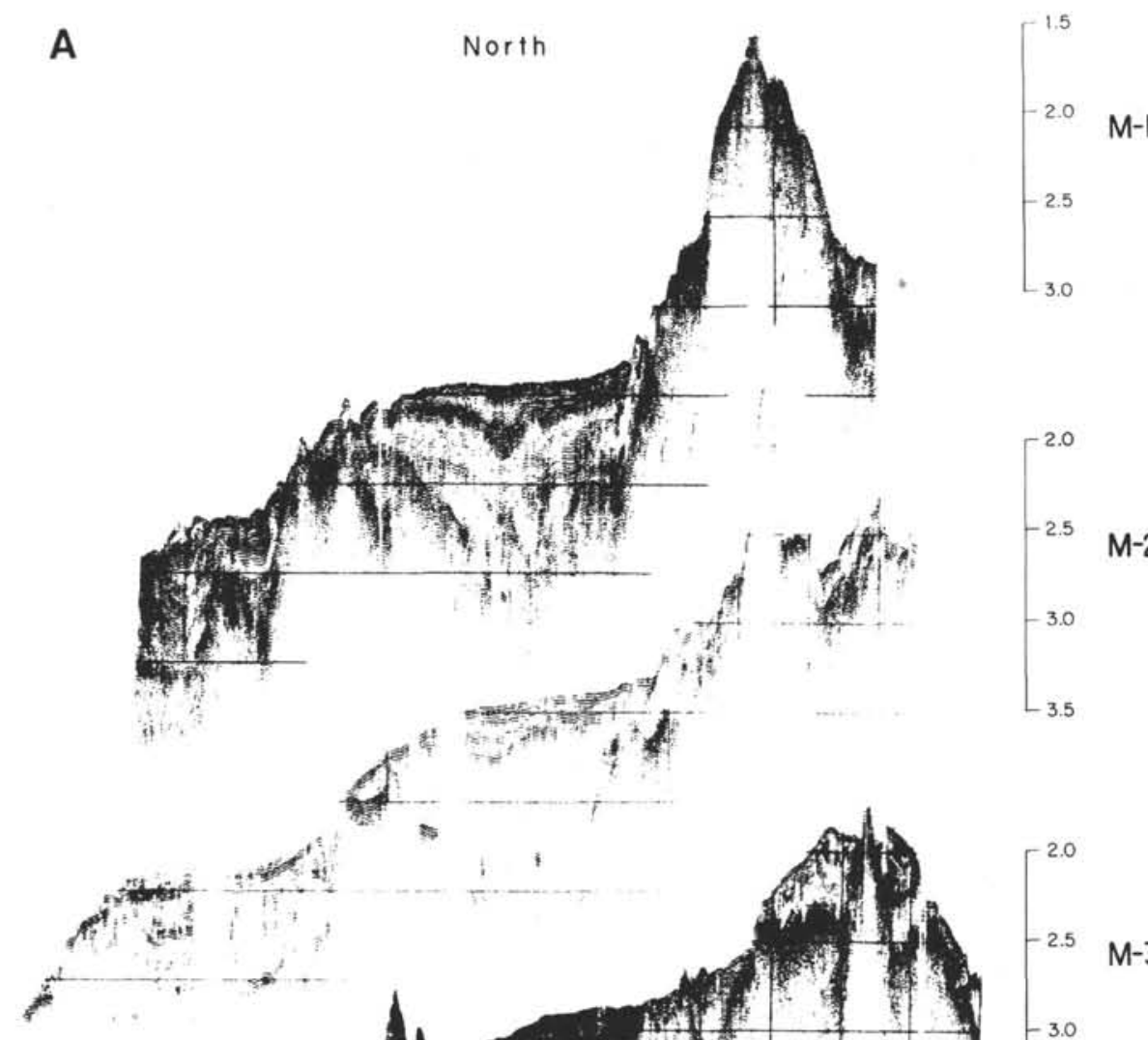

*5
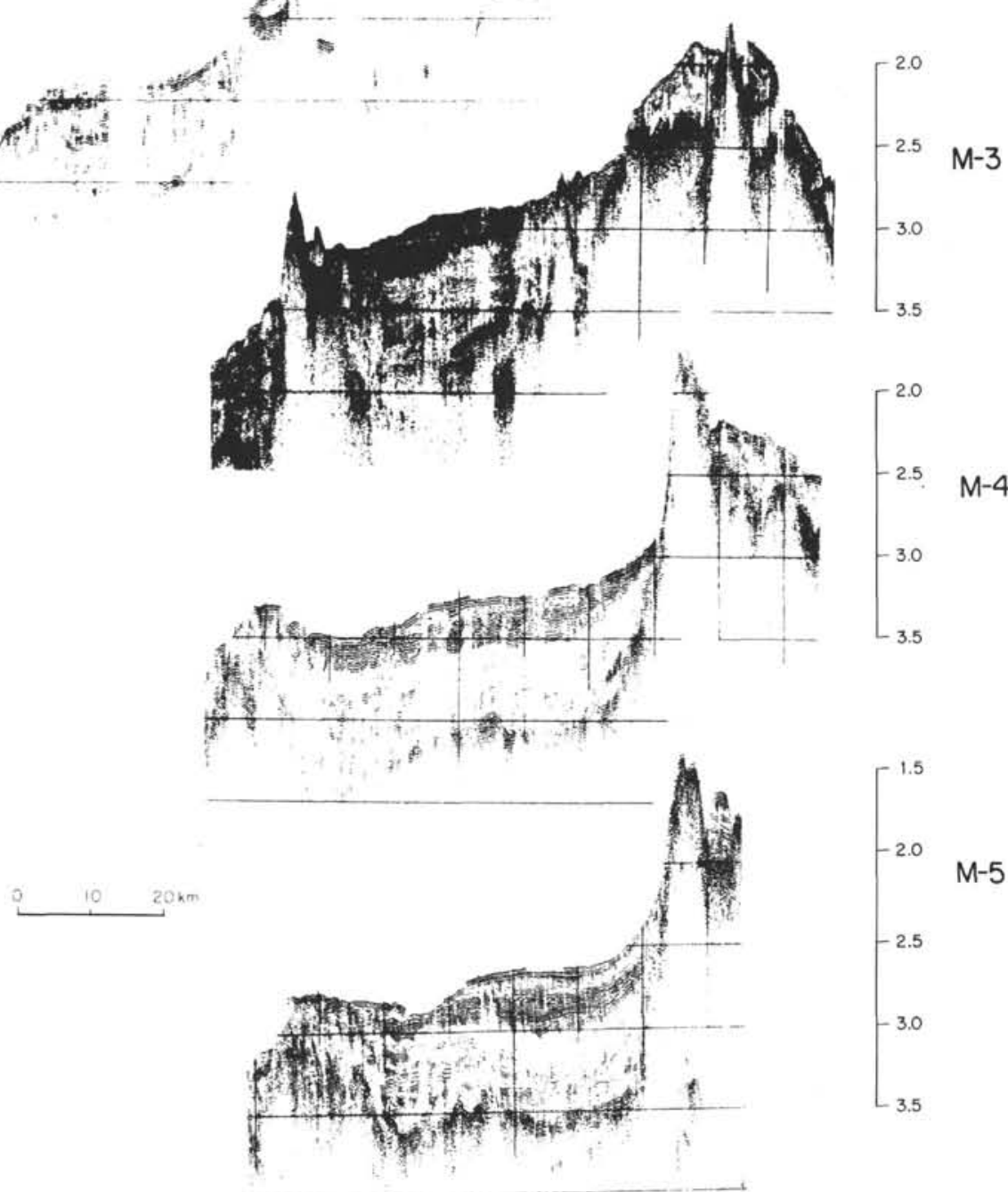

South

Figure 5. A. Analog records of single-channel seismic data from Conrad 2710. Profile locations are shown in Figure 4A. B. Line drawings of seismic records shown in Figure 4A. Seismic sequence boundaries are drawn heavier than internal reflectors. $\mathbf{V}$ pattern denotes the interpreted basement reflector. Interpreted fautts are shown by heavy lines. 
B
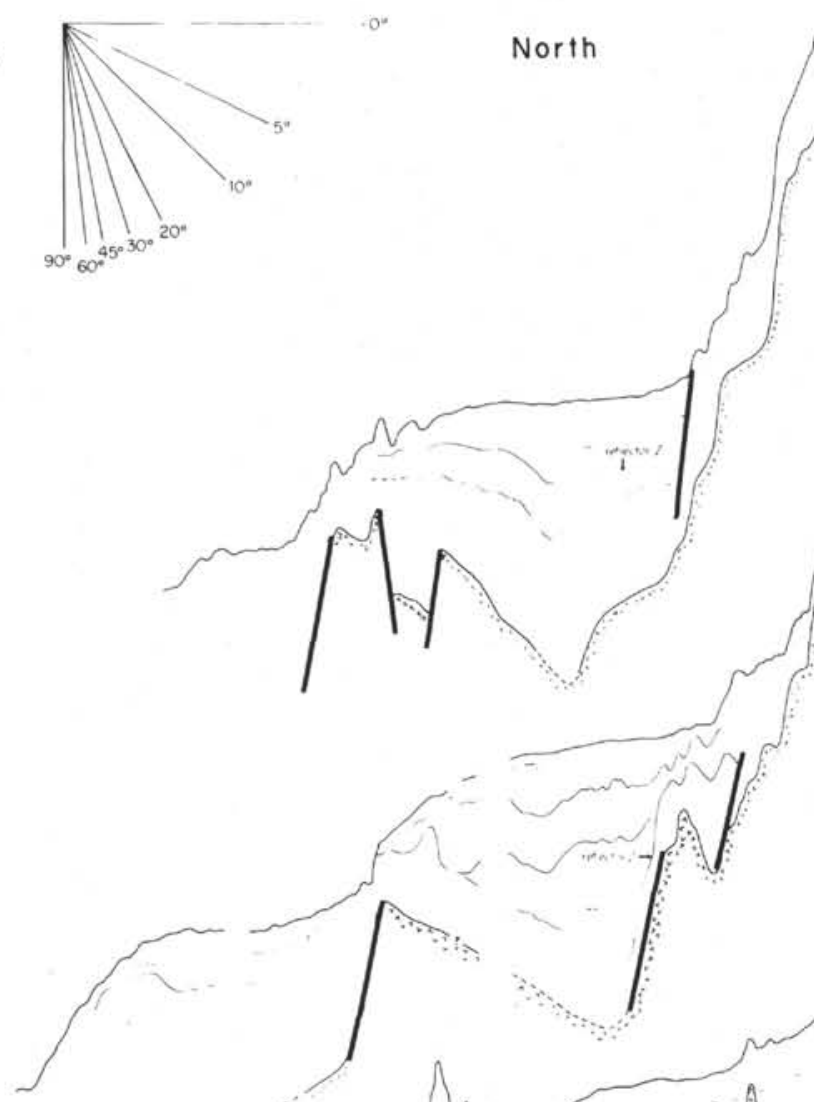

North
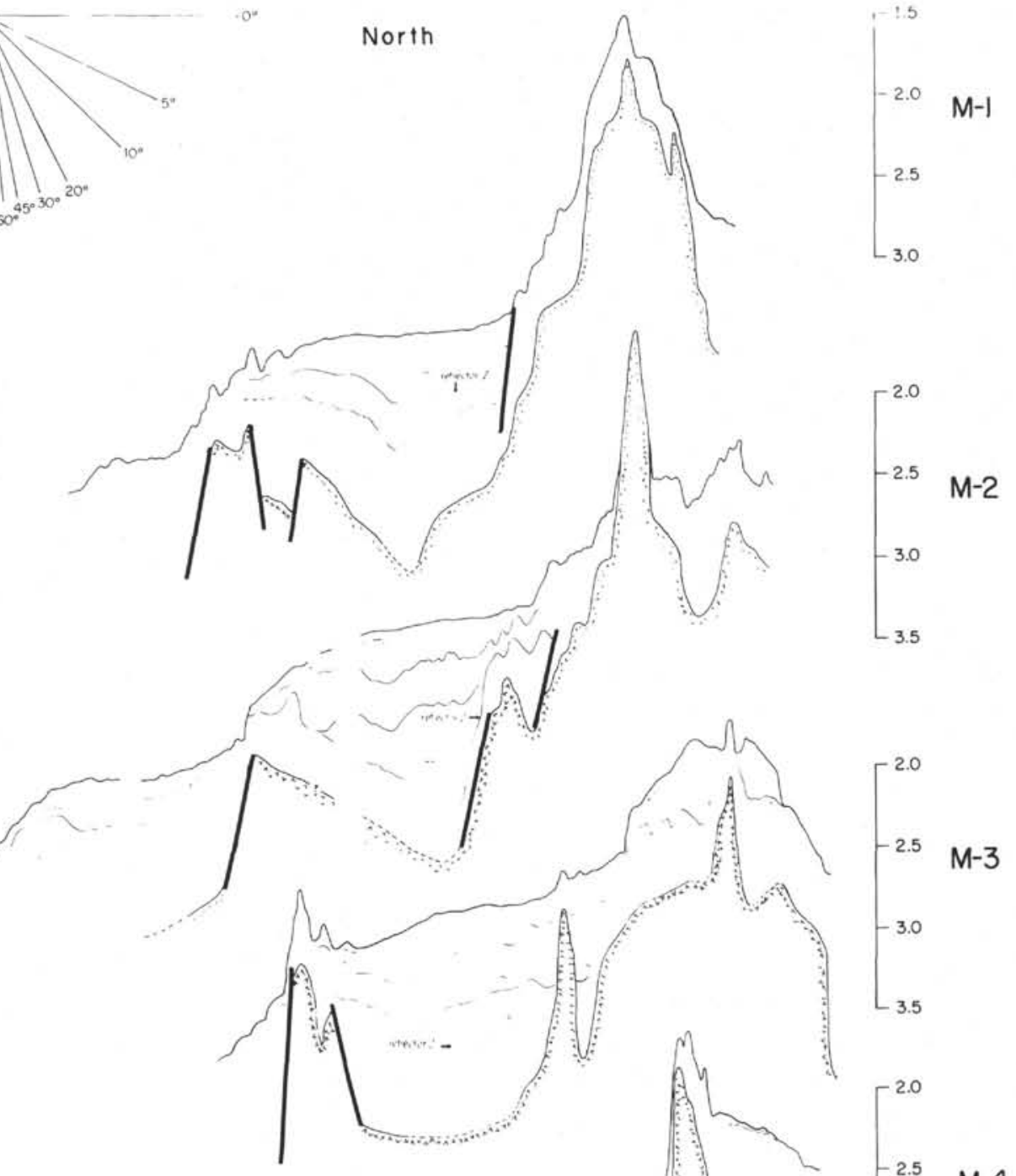

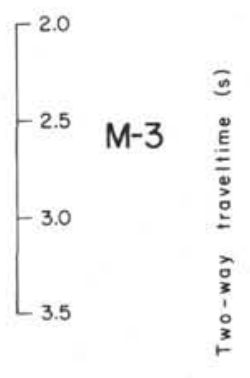

$-2.0$

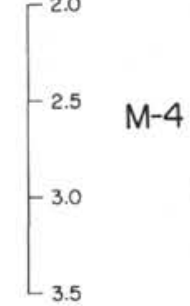

$10 \quad 20 \mathrm{~km}$
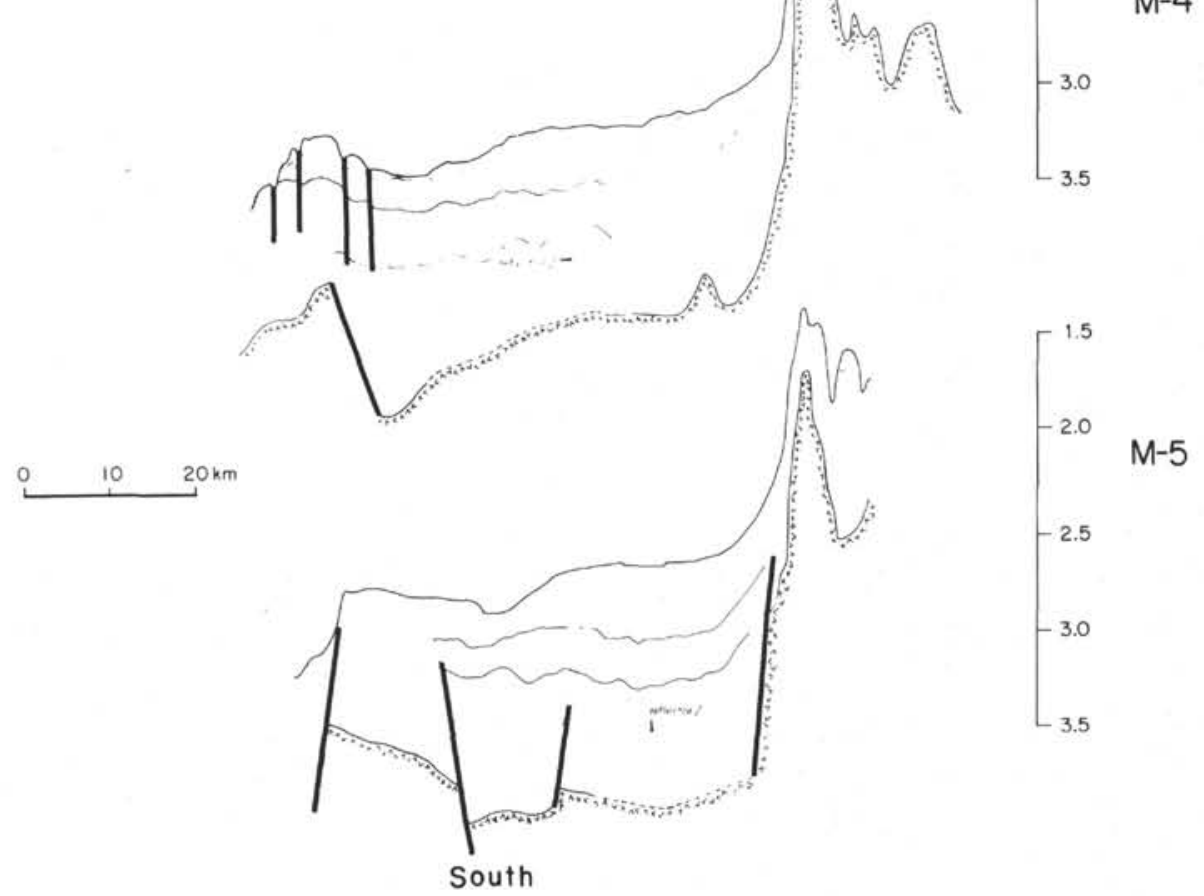

Figure 5 (continued). 
A

Northwest

Site 704

Southeost 12000n $\oplus$

19 Nov. 1986

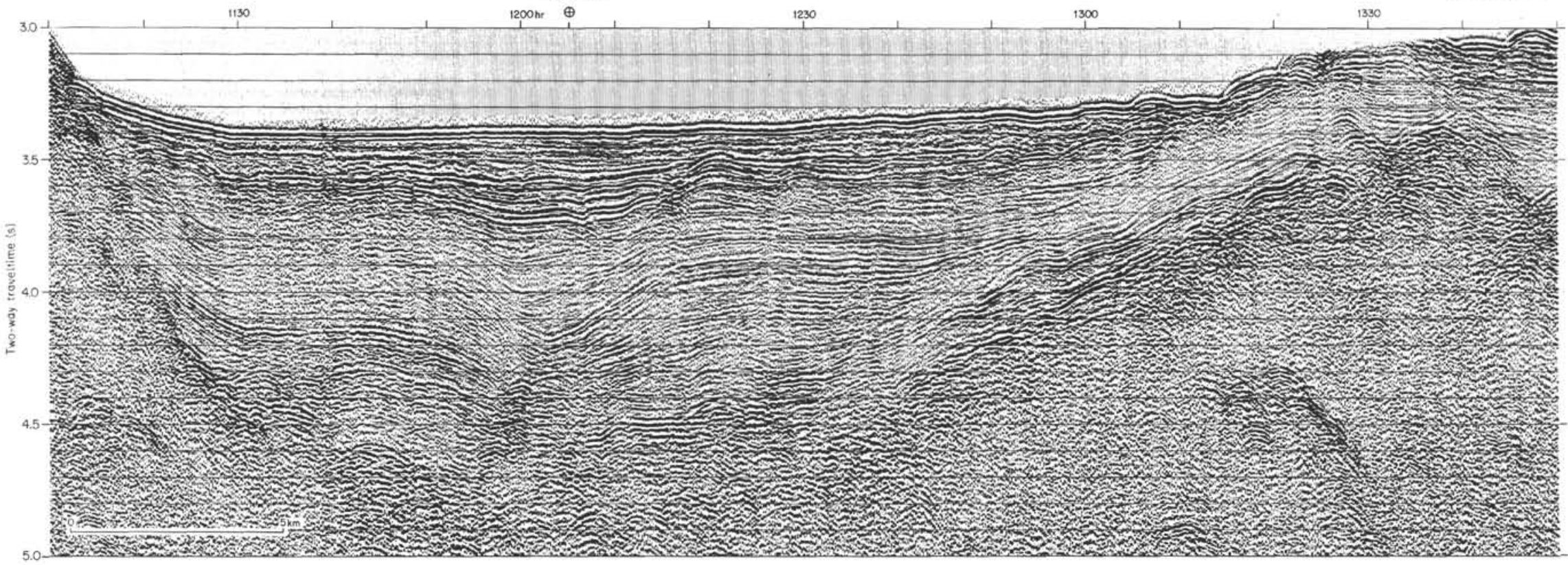




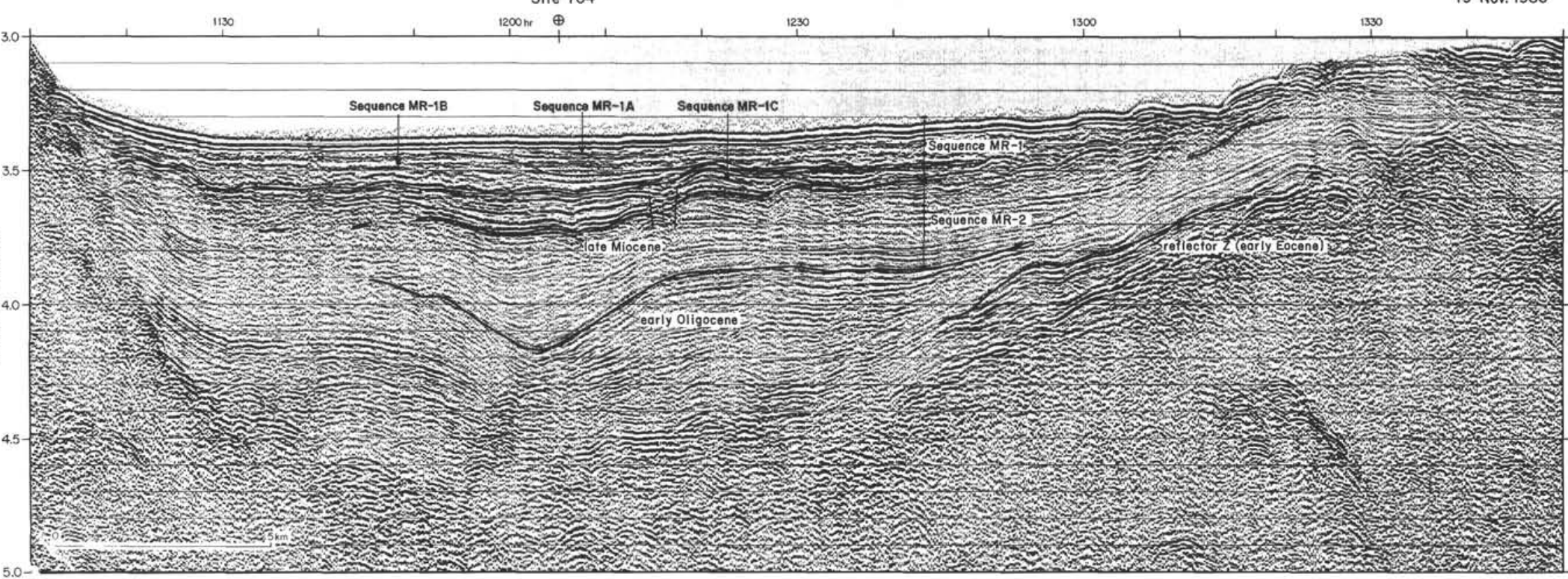

Figure 6. A. Digital seismic record of line M-6, oriented northwest-southeast through the basin, which passes closest to Site 704. The profile location is shown in Figure 4A (profile shown in this figure extends southeast only to the intersection of M-6 with M-2). Band-pass filtering and deconvolution were performed on the digital data. B. Interpretation of the seismic profile. Seismic sequences are identified; sequence MR-1 has been further subdivided into subsequences. Sequence MR-1 shows evidence of mass-flow and channel deposits. 


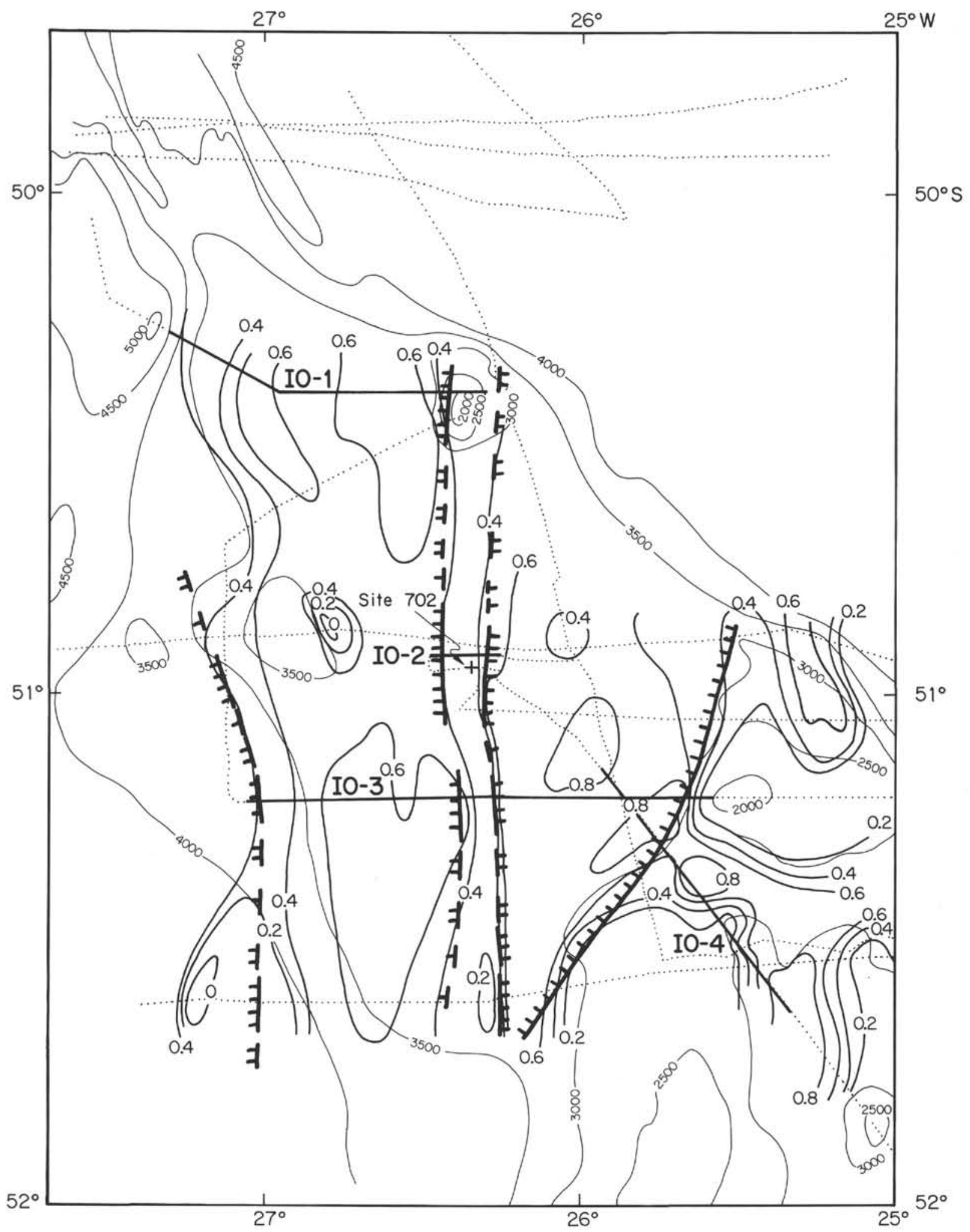

Figure 7. Sediment thickness (s twt) map for the central plateau of Islas Orcadas Rise. Contour interval is $200 \mathrm{~ms}(\sim 220 \mathrm{~m})$. Seismic data control is indicated by the dotted lines. Bathymetry from Brenner and LaBrecque (1988) is shown with light lines at $500-\mathrm{m}$ intervals; ODP Site 702 is marked. Heavy ticked lines indicate faults; the ticks identify the downthrown side. The surface of the sediment layer does not reflect the morphology of the faulted basement, suggesting erosion of high-standing blocks or differential sedimentation. Locations of the seismic profiles shown in Figure 8A are shown by heavy labeled lines. 
However, as discussed previously, the sedimentation rate may have been much higher during the Paleocene because of nearby sources of volcanic ash and mass wasting on the slopes of the seamounts, which would reduce the age estimate for the basement. On the other hand, lithification of the sediments in the deep basin would result in higher seismic velocity and therefore a thicker section, requiring a longer period of deposition. Limestone encountered at the bottom of Hole 704B in the center of the basin had a seismic velocity $4 \mathrm{~km} / \mathrm{s}$. Assuming a seismic velocity of $4 \mathrm{~km} / \mathrm{s}$ and a deposition rate of $100 \mathrm{~m} / \mathrm{m}$.y. yields an age of $65 \mathrm{~m}$.y. for the plateau basement.

Another piece of evidence pointing to two phases of volcanism on Meteor Rise is the distribution of magnetization on the rise, which is shown in Figure 3. Normally magnetized basement is observed west of the edge of the basin, whereas reversed magnetizations are implied by the negative correlation of anomaly and bathymetry in the seamount province. The sharp gradient near reflector $\mathrm{Z}$ suggests that reflector $\mathrm{Z}$ formed within the same polarity interval as the seamounts and in a different polarity interval than the plateau basement to the west. The normal magnetization of the plateau indicates that if its age is $\sim 70 \mathrm{Ma}$, it may have formed during Chron $\mathrm{C} 32 \mathrm{~N}$ $(\sim 73 \mathrm{Ma})$ or $\mathrm{C} 31 \mathrm{~N}(\sim 68 \mathrm{Ma})$. Reversed polarity intervals dominate between $\sim 63$ and $56 \mathrm{Ma}$, leading to a high probability that units emplaced during this interval would possess reversed magnetizations.

\section{DEPOSITIONAL HISTORY}

\section{Meteor Rise}

The spatial distribution of sediments on the southern Meteor Rise is shown in Figure 4A; SeaBeam bathymetry is shown in Figure 4B. The sediments infill a deep, restricted basin that has a V-shaped cross section in the north, resembling a tilted fault block basin (profiles M-1 and M-2, Fig. 5), and changes to a wider $U$-shaped cross section in the south (profiles M-3, M-4, and M-5, Fig. 5). The thickest sediments occur in the $\mathrm{V}(1.4 \mathrm{~s}$ twt $)$, whereas the $\mathrm{U}$-shaped profiles have a slightly reduced thickness, but a more even distribution (Figs. 4 and 5). Portions of the basin displaying V-shaped basement morphology possess sedimentary layers that mimic basement throughout the section.

The main features of the sedimentary fill within the basin on the Meteor Rise are an acoustically stratified upper layer that rests upon an acoustically transparent layer. An example of this is seen in the profile shown in Figure 6. Laterally discontinuous reflector packages exist within the transparent layer, the most prominent of which is reflector $\mathrm{Z}$, as discussed previously.

Site 704 was drilled in the axis of the sedimentary basin. The sedimentary record obtained at this site represents the highest resolution recording of carbonate content yet obtained from the Southern Oceans. We have examined the seismic stratigraphy in the vicinity of Site 704, from the digital single-channel seismic data obtained during Conrad Cruise 2710 in order to determine the depositional history of the basin. Profile M-6, which passes through the basin in the vicinity of Site 704 , is the most proximal high-resolution profile available for analysis (Figs. 4A, 6A, and 6B). Two main sequences are identified on the profile, the first containing several strong reflectors from the seafloor down to $3.6-3.78 \mathrm{~s}$ twt, labeled sequence MR-1, and another extending from the base of MR-1 down to a strong reflector that undulates sharply beneath the axis of the basin at $3.9-4.2 \mathrm{~s}$ twt, labeled sequence MR-2. These sequences were drilled at Site 704. The base of MR-1 marks a change from a high and constant carbonate/silica ratio below the boundary to high-frequency oscillations in the carbonate/silica ratio above (Shipboard Scientific Party, 1988c). The age of the basal part of MR-1 is late Miocene. At the base of sequence MR-2, the presence of numerous chert horizons within the chalk unit is suspected of giving rise to the strong reflections that occur just below the bottom of Hole 704B. The age of this seismic sequence boundary is estimated to be early Oligocene.

Sequence MR-1 is characterized by complex internal reflections. We have therefore further subdivided sequence MR-1 into three constituent subsequences. Sequence MR$1 \mathrm{~A}$ consists of flat-lying, undisturbed laminated sediments, which appear to onlap the northwestern edge of the profile, but pinch out to the southeast within the basin. Sequence MR-1A may be a partially eroded pelagic drape that rests unconformably upon sequence MR-1B. Sequence MR-1B is irregular in thickness and predominantly transparent. It infills a large depression that is bounded by a large seamount in the northwest and by an antiformal structure to the southeast. This irregular sequence, which appears to form an apron around the seamount, is interpreted to be a combination of mass-flow deposits and a uniform pelagic drape. Mass-flow deposits occur proximal to the basement high in the northwest, whereas the lack of evidence of reworked fossils at Site 704 (Ciesielski et al., this volume), as well as the diminished thickness of MR-1B near Site 704, indicates minimal input from mass flows near the drilling site. The structure upon which sequence MR-1B terminates in the east appears to be a discrete steep-sided channel, $<4$ $\mathrm{km}$ wide and $150 \mathrm{~ms}$ deep. Below sequence MR-1B is a sequence of laminated sediments (MR-1C) extending to the base of sequence MR-1. Sequence MR-1C appears to be undisturbed and of uniform thickness (100 ms), except near the axis of the basin, where it increases in thickness.

Sequence MR-2 is largely void of internal reflectors. Some internal reflections are present, but they lack adequate continuity to allow an interpretation of subsequences. The thickness of sequence MR-2 is quite variable. The thickness increases from $200 \mathrm{~ms}$ at the ends of profile M-6 to $300 \mathrm{~ms}$ at the edge of the basin to $400 \mathrm{~ms}$ at the axis of the basin. The cause of this variable thickness may be due to syndepositional folding or faulting or to differential sedimentation.

At the southeast end of profile M-6, all sequences except MR-1A pinch out against the seamounts. Approaching the seamounts the sequences become very chaotic. We interpret this area to be composed of multiple channels and mass flows.

\section{Islas Orcadas Rise}

The central plateau of Islas Orcadas Rise is covered by a 0.8 -s-thick (twt) sediment blanket (Fig. 7). Internal seismic horizons show uniform lateral thickness, but are locally disturbed by younger deformation (Figs. $8 \mathrm{~A}$ and $8 \mathrm{~B}$ ). The edges of the plateau and portions of the rise displaying rough topography (southeast) have irregular patches of sediment cover with strong lateral variation in the thickness of individual seismic units.

Seismic-reflection characteristics of the sediments on the central plateau delineate an upper seismic sequence (IOR-1, $0.2 \mathrm{~s}$ thick) with fine acoustic stratification above a middle sequence (IOR-2, $0.4 \mathrm{~s}$ thick) of low-frequency reflections that become weaker with depth. The basal part (sequence IOR-3) is characterized by a more than 0.2 -s-thick band of strong low-frequency seismic events in which an angular unconformity is present in the upper part of the sequence (line IO-3, Fig. 8).

Drilling at Site 702, on a horst structure in the middle of the central plateau of Islas Orcadas Rise (line IO-2, Figs. 7 and 8), 
A

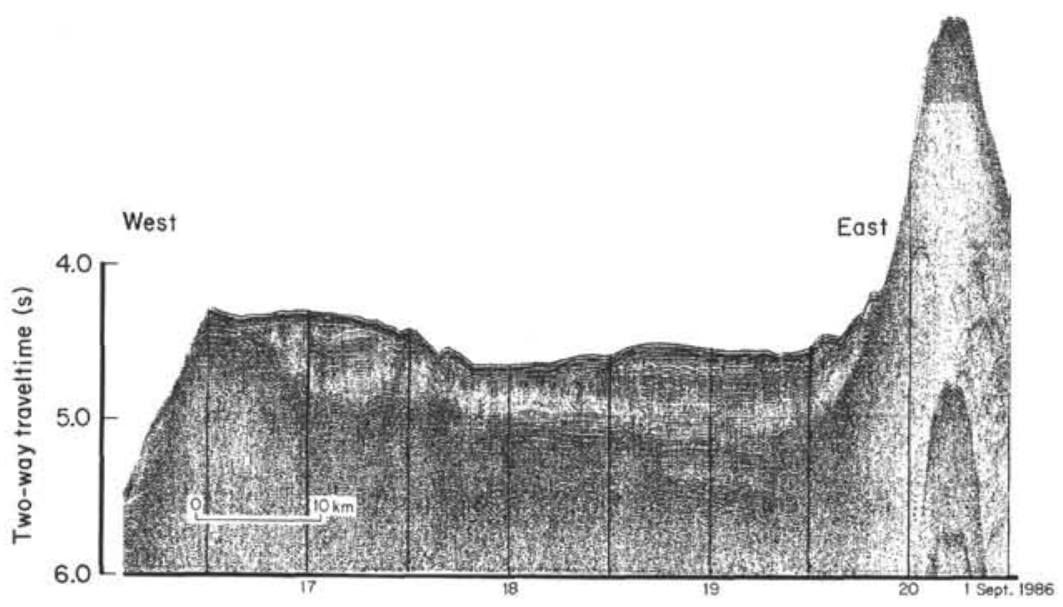

IO-1

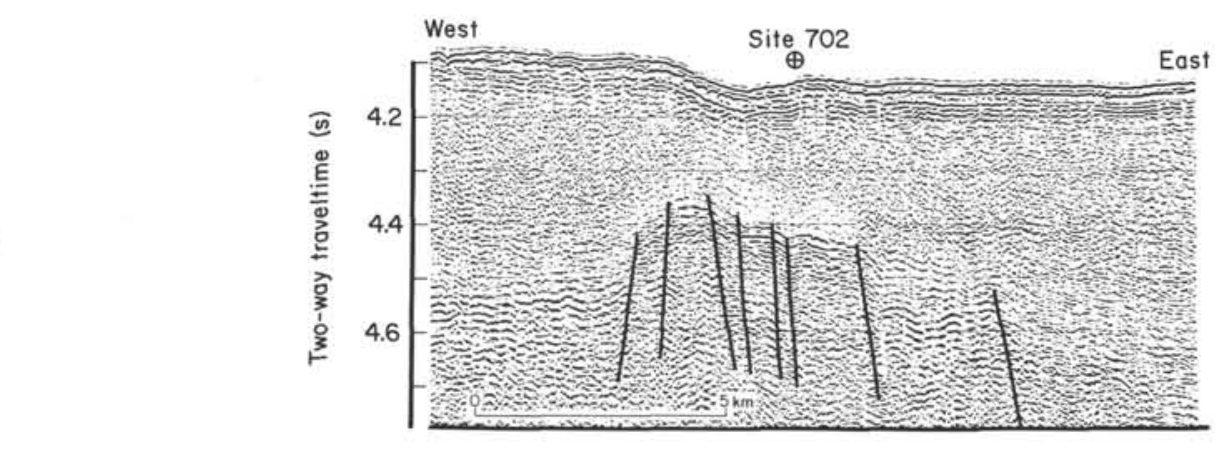

IO-2

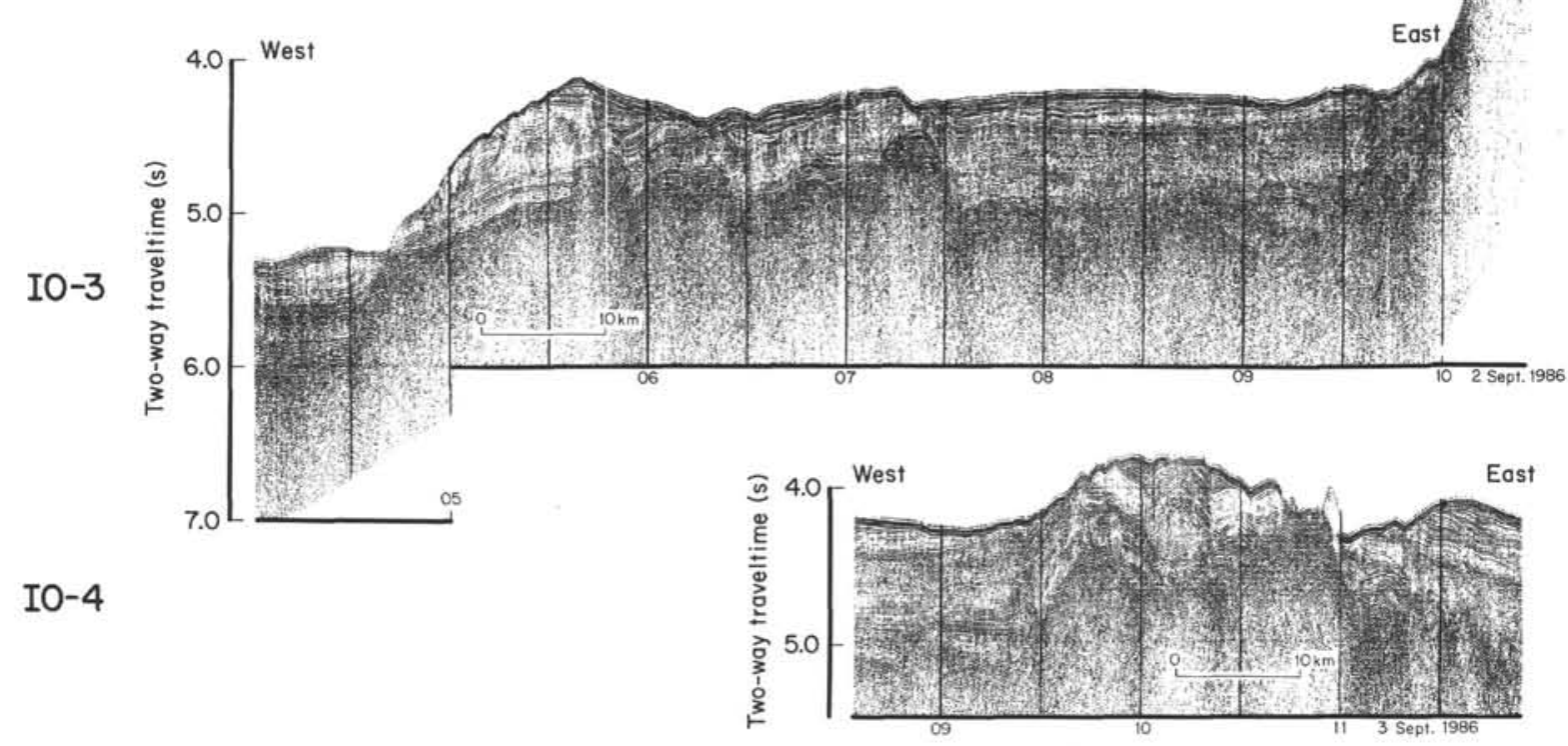

Figure 8. A. Digital seismic data for the Islas Orcadas Rise obtained by Polar Duke 0188 and JOIDES Resolution Leg 114. B. Line drawings of the seismic records. Corresponding features are indicated by arrows connected with dashed lines.

recovered a calcareous section with nannofossil diatom ooze of late Miocene and younger age to $32.8 \mathrm{~m}$ below seafloor (mbsf), overlying late Eocene nannofossil chalk (seismic sequence IOR-2). The drilling was terminated at $294.3 \mathrm{mbsf}$, where chert became abundant in the upper Paleocene indurated chalk. An important calibration point is the increasing abundance of chert at the bottom of the hole, which correlates with the beginning of the strong band of seismic reflections in the deepest part of the section representing the top of se- quence IOR-3. The tie between the upper ooze unit $(32.8 \mathrm{~m}$ thick), of late Miocene and younger age, and the regional seismic stratigraphy is uncertain, because of limitations in seismic data quality and resolution. This ooze unit may correspond to seismic sequence IOR-1 or be a thin, relatively uniform drape on top of the latter sequence on the central plateau of the Islas Orcadas Rise.

The smoothness of the seafloor above the horst trending north-south through the middle part of the central plateau on 
B

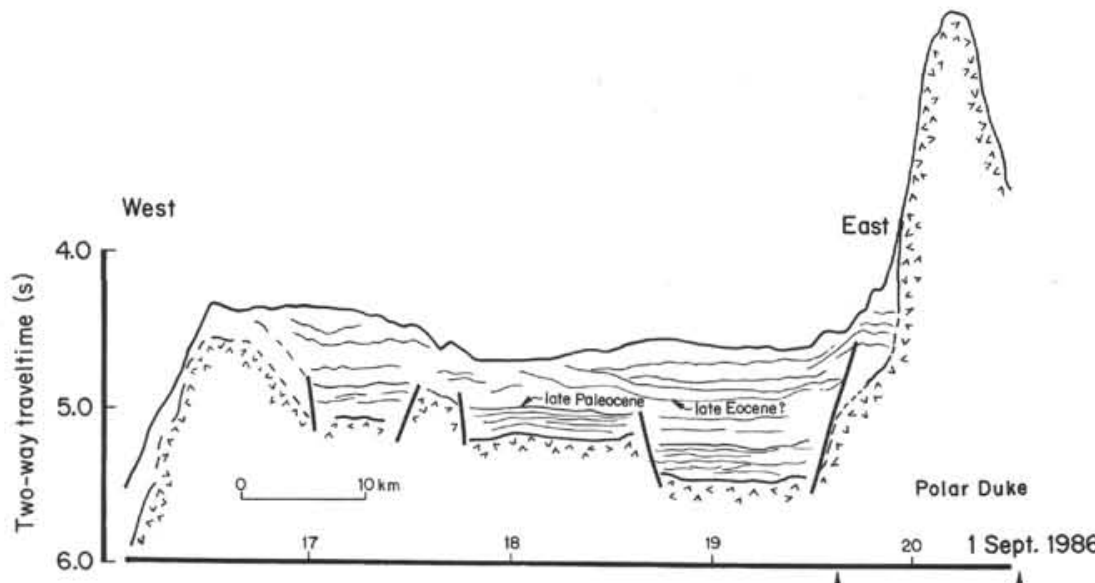

IO-2

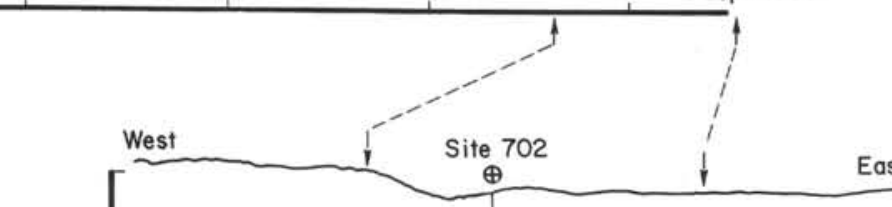

IO-3

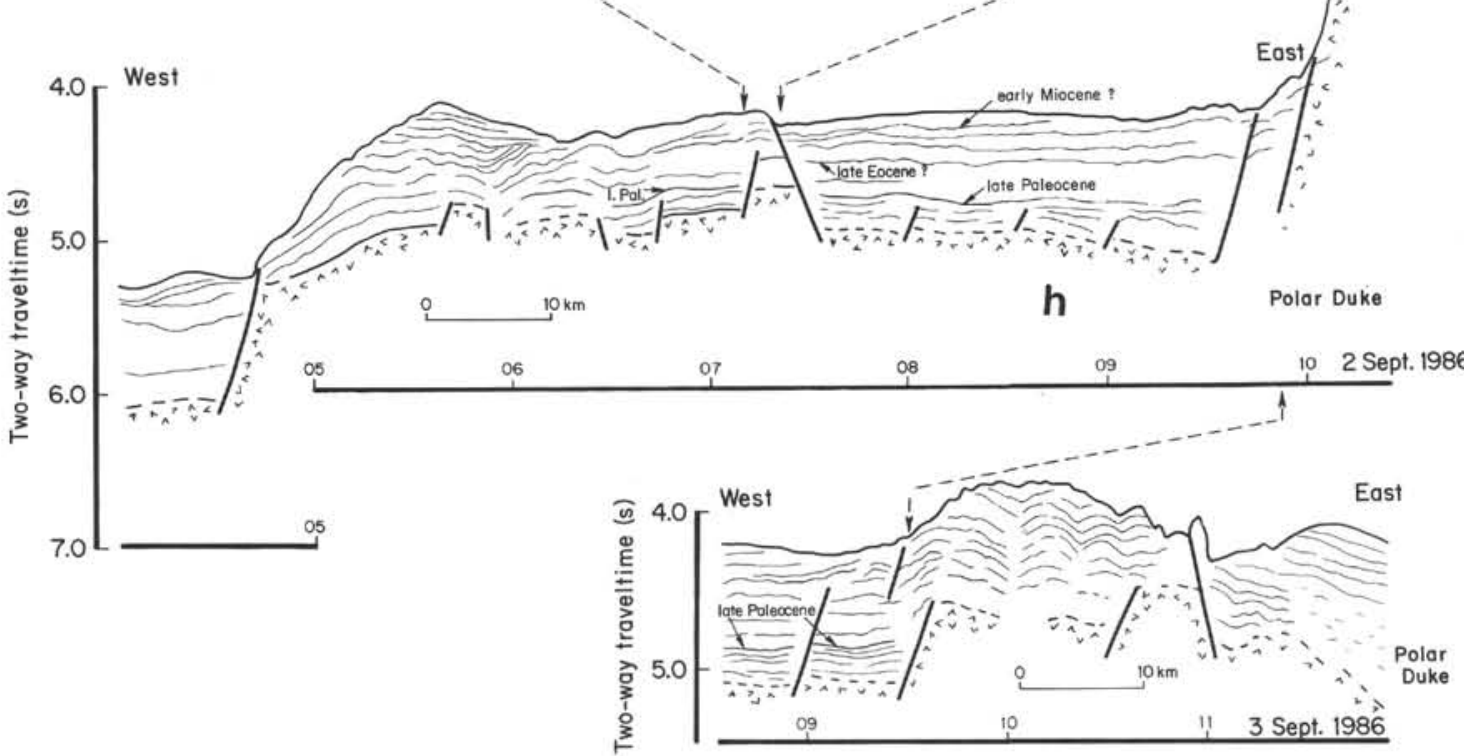

Figure 8 (continued).

Islas Orcadas Rise is particularly significant, because the internal reflections of seismic sequence IOR-2 suggest upbending/faulting of the late Eocene and older sediments near Site 702. Thus, post-late Eocene and pre-late Miocene erosion has smoothed most of the seafloor relief generated by tectonic movements within the same time span. In contrast, line IO-4 at the southern end of the rise shows evidence of compressional deformation affecting both basement and the entire sediment package.

\section{ORIGIN OF THE RISES}

Our knowledge of the structure and evolution of the conjugate rises has increased, but their origin is still problematic. Several hypotheses can be proposed to account for these anomalous features. Possible origins include (1) origin as rift shoulders created by effusive volcanism at a developing rift zone, such as has been proposed by Mutter et al. (1988) and White and McKenzie (1989); (2) origin as pseudofaults on 
a propagating rift (essentially the same as (1) but implying that the rises are time transgressive); and (3) construction by midplate volcanism, perhaps at a "hot spot."

A key question concerning the origin of the rises is whether they were created as a consequence of the formation of a new spreading axis in old ( $20 \mathrm{~m}$.y.) oceanic crust, or whether they represent a site of intraplate volcanism that was exploited when the ridge crest jumped. Several significant observations can help in evaluating the aforementioned processes in terms of their probable contribution to forming the rises. One observation is the asymmetry of the rises. The Islas Orcadas Rise is on average $500 \mathrm{~m}$ deeper than Meteor Rise. This observation was explained by Raymond and LaBrecque (1988) as a consequence of a positive regional depth anomaly in the Agulhas Basin, which accounts for the shallower depths on Meteor Rise. Examination of the seismic data, however, reveals fundamental differences in basement structure between the two rises, which argues against a purely symmetrical mechanism for producing the relief. The Meteor Rise has rugged seamounts and a deep basin; the basement flooring the basin is suggestive of rotated fault blocks such as are produced at listric faults. The Islas Orcadas Rise is smooth (except for its seamounts in the east) and has experienced high-angle faulting. Hence the rift shoulder hypothesis, which predicts symmetrical constructional volcanic features, cannot fully explain the origin of the rises, unless their differences are mainly the result of their mechanical response to rapid subsidence as the lateral temperature gradient decreased. The characteristics of the Meteor Rise-Islas Orcadas Rise system depart significantly from the scars of ridge crest jumps that have been studied in the Pacific Basin (Mammerickx and Sandwell, 1986), which all have similar characteristics despite differences in the age of the rifted crust (10-18 m.y.). The Pacific examples all show clean, linear scarps that display remarkable symmetry.

A second significant observation is the age of the crust bordering the rises. The margins of the rises are nearly isochronal (Figs. 2A and 2B). The identification of anomaly 25 at the edge of the Meteor Rise, and adjacent to the guyot north of Meteor Rise, could be taken as evidence that the new spreading center propagated south. However, the distance from anomaly 24 to the older edges of the rises is fairly constant, arguing that the greater amount of volcanic construction in the south has simply obscured the expression of anomaly 25 adjacent to the southern Meteor Rise. It would therefore appear that a propagating rift mechanism is unsatisfactory in explaining the origin of the rises as pseudofaults.

The rises evolved into plateaus in the south, deviating significantly from the linear structures that would be expected if they formed by some rifting mechanism. One explanation of the plateau nature of the rises is that they formed near a mantle melting anomaly (and/or the South American-AfricanAntarctica triple junction), which supplied a greater amount of magma to the southern ends of the rises. Duncan (1981) has proposed that excess volcanism along a line from the Karoo in South Africa to Bouvet Island is the result of the Bouvet hot spot. Indeed, the chemistry of basement basalt samples recovered at Site 703 on the Meteor Rise is consistent with a magma source derived from a mantle plume (M. Perfit, pers. comm., 1989). However, midplate volcanism cannot explain the linear trend of $330^{\circ}$, which is perpendicular to Duncan's hot-spot track and the direction of migration of the triple junction (LaBrecque, 1986). The distribution of magnetic anomalies bordering the rises indicates that a propagating rift mechanism is not a viable explanation for the origin of the Meteor Rise and Islas Orcadas Rise. Furthermore, the plateau nature of the rises, and the differences in basement structure between them, suggest that rift shoulder uplift cannot wholly
Table 1. Paleodepth estimates for the Islas Orcadas and Meteor rises.

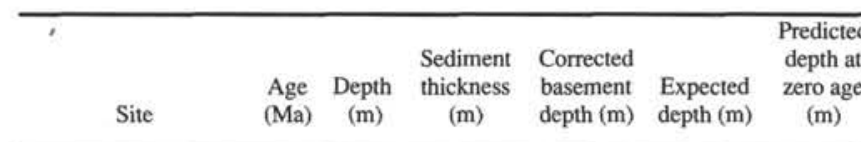

\begin{tabular}{|c|c|c|c|c|c|c|}
\hline \multicolumn{7}{|l|}{ Islas Orcadas Rise } \\
\hline Central plateau & 70 & 3135 & 682 & 3500 & $\begin{array}{r}1563 \\
3061\end{array}$ & $\begin{array}{r}1963 \\
439\end{array}$ \\
\hline Site 702 (horst) & 70 & 3084 & 220 & 3201 & $\begin{array}{r}a \\
b \\
1583 \\
3081\end{array}$ & $\begin{array}{r}1638 \\
140\end{array}$ \\
\hline \multicolumn{7}{|l|}{ Meteor Rise } \\
\hline Site 714 (plateau) & 70 & 2580 & 2200 & 3169 & $\begin{array}{r}1563 \\
3061\end{array}$ & $\begin{array}{r}1606 \\
108\end{array}$ \\
\hline Site 703 (seamounts) & 60 & 1800 & 364 & 1995 & 2711 & +718 \\
\hline
\end{tabular}

a Subsidence is calculated as the subsidence that the underlying plate would experience from 20 to $90 \mathrm{~m} . \mathrm{y}$. of age (an estimate of the age of the underlying lithosphere). No thermal rejuvenation is assumed.

b

Subsidence from 70 to $60 \mathrm{Ma}$ is $351 \mathrm{~m}$ (calculated as the subsidence that the underlying plate would experience as it ages from 20 to $30 \mathrm{~m}$.y. old). At $60 \mathrm{Ma}$ the thermal age is reset during rifting and the topography then subsides from zero age for $60 \mathrm{~m} . \mathrm{y}$.

explain the origin of the rises. Excessive volcanism resulting from a melting anomaly (anomalous mantle temperature or chemistry) south of the rises could explain the formation of the plateau portions of the rises during extension associated with the ridge axis jump, or alternatively as midplate volcanic features preceding the ridge jump.

\section{PALEODEPTH ESTIMATES}

The Late Cretaceous-early Tertiary Meteor Rise-Islas Orcadas Rise system was bounded to the north by shallow fracture zone topography (Raymond and LaBrecque, 1988) and to the south by spreading ridges. Therefore, the rises created a barrier, inhibiting circulation of the South Atlantic and Southern Ocean water masses. The timing of subsidence of this topography, and/or breaks in it, is of great interest because of the profound change in oceanic circulation and faunal evolution that would accompany the breaching of this barrier. We have adopted the simple thermal cooling approach to calculate the paleodepth of the rises, which was shown by Detrick et al. (1977) to satisfactorily reproduce independent paleodepth estimates obtained by Deep Sea Drilling Project sampling on other aseismic plateaus. The input parameters for the paleodepth calculations and results are presented in Table 1; the estimates are plotted in Figure 9, along with the other estimates of Detrick et al. (1977). An estimate of early Eocene $(\sim 56 \mathrm{Ma})$ for subsidence of the seamount ridge platform on Meteor Rise (i.e., the base of the seamounts) below sea level is determined from Site 703, assuming an age of $60 \mathrm{Ma}$. Benthic foraminifers indicate that Site 703 had a paleodepth greater than $600 \mathrm{~m}$ during the Eocene (Shipboard Scientific Party, 1988b), in agreement with the calculation. Adjacent seamounts were near sea level, as redeposited microfossils include neritic diatoms. This is in accord with the present topography around Site 703 .

Paleodepth estimates for Sites 702 and 704 cannot be as simply calculated as in the case of Site 703. The assumed formation of the plateau portions of the rises during the Maestrichtian, and later rifting at $\sim 60 \mathrm{Ma}$, implies that the rises have been thermally rejuvenated. Therefore, their subsidence history is more complex. For these sites the paleodepth was calculated by two methods: (1) simple thermal subsidence since formation at $70 \mathrm{Ma}$ on a $20-\mathrm{m}$.y-old plate and (2) slow subsidence from 70 to $60 \mathrm{Ma}$ with the older underlying plate, followed by thermal rejuvenation at $60 \mathrm{Ma}$ that reset the 

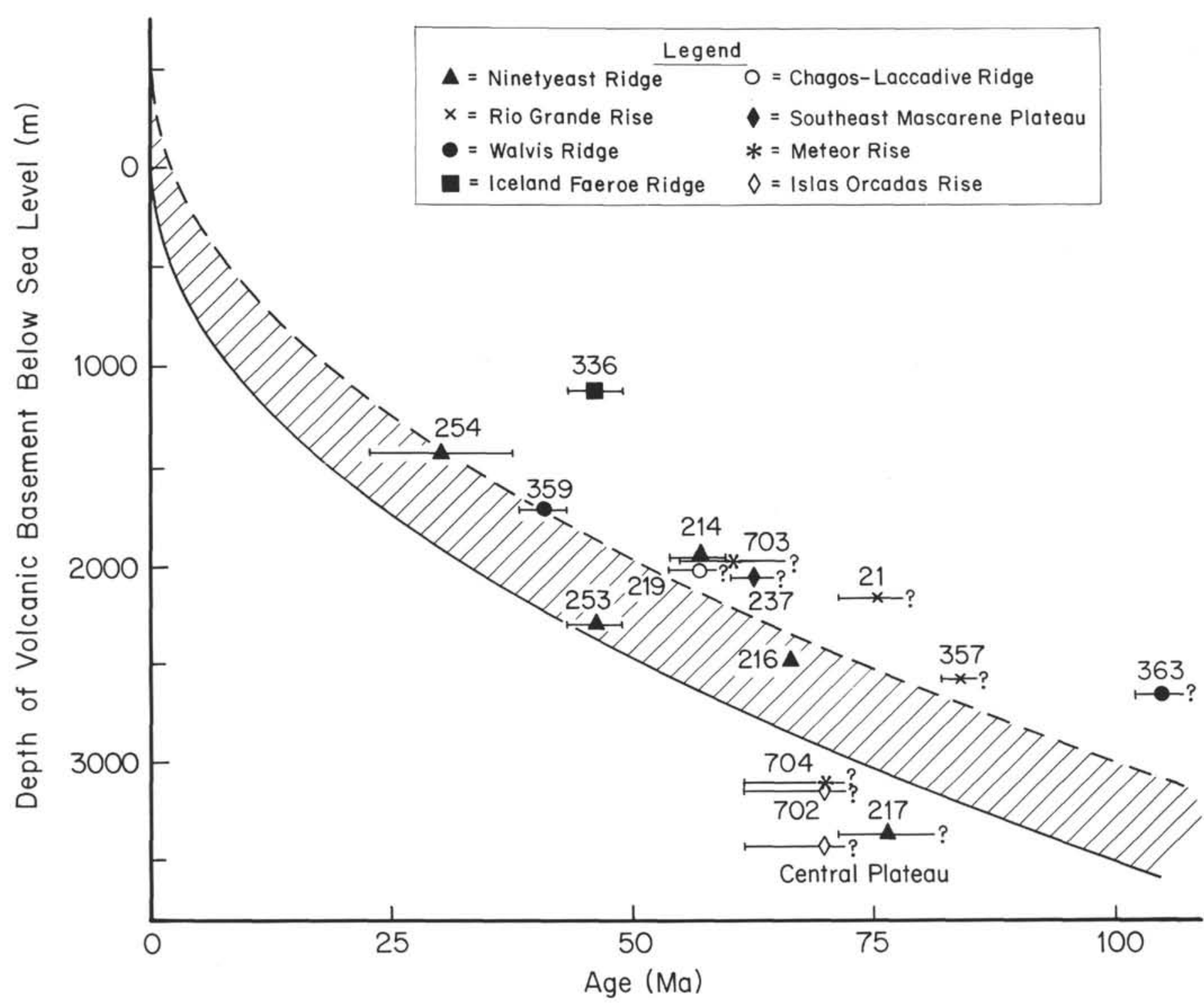

Figure 9. Paleodepth estimates for Sites 702, 703, and 704 and the central plateau of Islas Orcadas Rise, plotted with estimates for other aseismic plateaus from Detrick et al. (1977). The solid line is the empirical depth-age curve of Parsons and Sclater (1977); the dashed line is same subsidence curve for topography that formed $500 \mathrm{~m}$ above sea level.

subsidence curve back to zero age (fast subsidence). The first method predicts that the plateaus formed well below sea level, at $1500-2000 \mathrm{~m}$ depth. The second method predicts that the plateaus reached depths between $100 \mathrm{~m}$ (Meteor Rise) and 450 $\mathrm{m}$ (Islas Orcadas Rise) at the time of formation. Benthic foraminifers recovered at Site 702 (Islas Orcadas Rise) indicate paleodepths of $1000-2000 \mathrm{~m}$ in the upper Paleocene section (Katz and Miller, this volume). Estimates of paleodepth at $60 \mathrm{Ma}$ for the Islas Orcadas Rise are 2314 and 1545 $\mathrm{m}$ (methods 1 and 2, respectively) for the central plateau and 1989 and $1246 \mathrm{~m}$ for Site 702. Clearly, these paleodepth estimates are all consistent with the interpreted foraminiferal depths; unfortunately, the benthic foraminifer data cannot be used to distinguish which set of assumptions used to calculate the paleodepth estimates yields better predictions. The depth estimates shown in Figure 9 indicate that only Site 703 could have formed on-ridge, even given the uncertainty in the basement age for the rises.

The importance of Neogene faulting to the basement morphology on Islas Orcadas Rise makes the estimates of paleodepth derived from present basement depth less meaningful. If the Neogene faulting on Islas Orcadas Rise was all normal faulting, then the paleodepth from Site 702 would be more representative of the ancient plateau depth; conversely, if the faulting is reverse, the greater paleodepth calculated from the smooth basement may apply. The calculated paleodepths are expected to bracket the true paleodepth.

The paleodepth estimates suggest that the rises constituted a barrier to shallow- and deep-water circulation between the South Atlantic and antarctic water masses. The shallow topography may have remained above $500 \mathrm{~m}$ depth from $\sim 70$ until $\sim 55 \mathrm{Ma}$. However, the presently known bathymetry suggests that important passageways for interbasin circulation existed between Meteor Rise and the Agulhas Fracture Zone and in the Falkland Gap (near the intersection of Islas Orcadas Rise with the Falkland Fracture Zone). These passageways deserve more detailed investigation to clarify their importance to water mass communication from the Late Cretaceous through the middle Eocene. 


\section{DISCUSSION}

Our synthesis of data from the site surveys and drilling results from Leg 114 has yielded four major observations: (1) despite a general symmetry, there appear to be some significant differences in the structure of the Meteor and Islas Orcadas rises; (2) two volcanic episodes are apparent on the Meteor Rise; (3) the Islas Orcadas Rise has been subjected to compression involving both basement and sediments, which may have occurred in multiple episodes, the most recent involving the entire section; and (4) the late Miocene to Holocene sedimentary section drilled at Site 704 within the basin on the Meteor Rise appears to contain some mass-flow input.

The main differences between the two rises lie in the ruggedness of the basement, pear-shaped vs. ridge morphology, depth, sediment character and distribution, faulting, and the presence of reflector $\mathrm{Z}$ on Meteor Rise. Some differences can be attributed to post-rifting evolution, such as late Neogene faulting on Islas Orcadas Rise. Volcanic construction was greater at the southern end of both rises and greater, or more long-lived, on the Meteor Rise than the Islas Orcadas Rise. The differences in basement structure of the two rises, and the spatial distribution of volcanism, argues for some asymmetry in the processes that formed the rises.

The sediment distribution on Meteor Rise is very uneven. The thickness of individual sequences indicates that differential sedimentation, filling in depressions in the undulating basement, and/or syndepositional folding or faulting occurred. The upper sedimentary section on Meteor Rise is composed of pelagic sediments intercalated with mass-flow and channel deposits. On the other hand, sedimentation on the Islas Orcadas Rise appears to have been more quiescent, but the flat-lying layers are disrupted by late Neogene faulting. The differences in the sedimentation patterns on the Islas Orcadas Rise and Meteor Rise reflect differences in tectonic activity during evolution of the rises, as well as current action.

We propose that the basement of the two rises formed in the Late Cretaceous, just prior to the ridge jump, and subsequently split when seafloor spreading initiated at the new spreading axis at $\sim \mathrm{C} 25(59 \mathrm{Ma})$. The seamount province drilled at Site 703 is interpreted as a younger phase of volcanism, based on the presence of a strong reflector within the basin associated with the seamounts, the depth of the province, and its magnetic signature. This younger phase of volcanism is estimated to be contemporaneous with the initiation of seafloor spreading. Alternatively, the rises may have formed during a short interval in the early Paleocene at the time of the ridge jump, implying that the rises formed $1000 \mathrm{~m}$ below sea level, except for the seamounts on the eastern edge of Meteor Rise.

\section{ACKNOWLEDGMENTS}

We gratefully acknowledge W. Haxby and L. Lawver for suggestions leading to improvement of the manuscript. We would like to thank B. Clement and L. Dearmont for their help and patience and B. Batchelder for drafting the figures. C.A.R, and J.L.L. also thank the staff of the Seismological
Observatory in Bergen for their hospitality. This research was supported by National Science Foundation contract OCE-8707681. Lamont-Doherty Geological Observatory Contribution 4651 .

\section{REFERENCES}

Barker, P. F., 1979. The history of ridge-crest offset at the Agulhas Fracture zone from a small-circle geophysical profile. Geophys. J. R. Astron. Soc., 59:131-145.

Brenner, C., and LaBrecque, J. L., 1988. Bathymetry of the Georgia Basin and environs. In Ciesielski, P. F., Kristoffersen, Y., et al., Proc. ODP, Init. Repts., 114: College Station, TX (Ocean Drilling Program), 22-26.

Ciesielski, P. F., Kristoffersen, Y., et al., 1988. Proc. ODP, Init. Repts., 114: College Station, TX (Ocean Drilling Program).

Detrick, R. S., Sclater, J. G., and Thiede, J., 1977. The subsidence of aseismic ridges. Earth Planet. Sci. Lett., 34:185-198.

du Plessis, A., 1977. Seafloor spreading south of the Agulhas Fracture Zone. Nature, 270:719-721.

Duncan, R. A., 1981. Hotspots in the Southern Oceans-an absolute frame of reference for motion of the Gondwana continents. Tectonophysics, 74:29-42.

Haxby, W. F., and Raymond, C. A., 1989. Tectonic evolution of the Agulhas Fracture Zone and Basin: deformations at a large offset transform resulting from changing relative plate motion. EOS, Trans. Am. Geophys. Union, 70:1353.

Kent, D. V., and Gradstein, F. M., 1986. A Jurassic to Recent chronology. In Tucholke, B. E., and Vogt, P. R. (Eds.), The Geology of North America: The Western Atlantic Region. Geol. Soc. Am. DNAG Ser., 1:45-50.

LaBrecque, J. L. (Ed.), 1986. South Atlantic Ocean and Adjacent Continental Margin, Atlas 13. Ocean Margin Drilling Program Atlas Ser., 13.

LaBrecque, J. L., and Hayes, D. E., 1979. Seafloor spreading history of the Agulhas Basin. Earth Planet. Sci. Lett., 45:411-428.

Mammerickx, J., and Sandwell, D., 1988. Rifting of old oceanic lithosphere. J. Geophys. Res., 91:1975-1988.

Mutter, J. C., Buck, W. R., and Zehnder, C. M., 1988. Convective partial melting. 1. A model for the formation of thick basaltic sequences during the initiation of spreading. J. Geophys. Res., 93:1031-1048

Parsons, B., and Sclater, J. G., 1977. An analysis of the variation of bathymetry and heat flow with age. J. Geophys. Res., 82:803-827.

Raymond, C. A., and LaBrecque, J. L., 1988. Geophysical signatures of the Agulhas Fracture Zone Ridge and Meteor Rise. In Ciesielski, P. F., Kristoffersen, Y., et al., Proc. ODP, Init. Repts., 114: College Station, TX (Ocean Drilling Program), 27-34.

Shipboard Scientific Party, 1988a. Site 702. In Ciesielski, P. F., Kristoffersen, Y., et al., Proc. ODP, Init. Repts., 114: College Station, TX (Ocean Drilling Program), 483-548. 1988b. Site 703. In Ciesielski, P. F., Kristoffersen, Y., et al., Proc. ODP, Init. Repts., 114: College Station, TX (Ocean Drilling Program), 549-620.

1988c. Site 704. In Ciesielski, P. F., Kristoffersen, Y., et al., Proc. ODP, Init. Repts., 114: College Station, TX (Ocean Drilling Program), 621-796.

White, R. S., and McKenzie, D., 1989. Magmatism at rift zones: the generation of volcanic continental margins and flood basalts. $J$. Geophys. Res., 94:7685-7729.

Date of initial receipt: 18 November 1989

Date of acceptance: 29 January 1990

Ms 114B-172 